\title{
A STUDY ON SPEAKING SKILL ACTIVITIES IN AR-ROHMAH ENGLISH COMMUNITY PROGRAM IN SMA AR-ROHMAH MALANG
}

\author{
Adnin Hayatinnufus \\ SDIT Persatuan Islam Brebes \\ eden07kawaii@gmail.com
}

\begin{abstract}
Ar-rohmah English Community is an extracurricular program which provides time and creates opportunity to learn English speaking skill. The aims of this study are to describe kinds of speaking activities used in Ar-Rohmah English Community Program in SMA Ar-Rohmah Malang, to find out the problems related to teaching and learning English speaking skill activities in AEC Program and to investigate the solutions for the problems. The use of research design in this study was descriptive qualitative in which the instrument used to get the data were observation, questionnaire and interview. It was presumed as the proper design in order to attain the purpose in overcoming and solving the research problems. This study obtained the data from twenty-four students and two English teachers who were involved in the AEC Program. After analyzing the data, it is found that English teachers use seven speaking activities in Ar-Rohmah English Community Program. Those seven activities are free speaking, card game, watching movie, interview, storytelling, science writing presentation and dialogue activities. Furthermore, the problems found related to teaching and learning English speaking skill are derived from linguistic and non-linguistic factors. From linguistic factors, it is found that the students face the difficulty on mastering vocabulary, choosing appropriate grammar, lacking of pronunciation experience and not habituated with English. Moreover, from non-linguistic factor, they are reluctant to speak in English because they are inhibited, have nothing to say, have low participation and feel ease and safe using mother tongue language. Besides, the teachers face the difficulty such as get tired to handle a large class with only two teachers, confused to choose suitable activity, do not remember students' names, hard to motivate the students to speak in English and lack of preparation time. In addition, other activity which is Pandu Hidayatullah influences the students' passion toward AEC Program. Dealing with those problems, the teachers keep creating creative, fun and interesting activity to improve the students' vocabulary, grammar, pronunciation and familiarized the students with English. By creating regulations, they solve the problems of students' low motivation to use English hard to push the students using English
\end{abstract}

Keywords: language program, speaking activity, problems in teaching and learning English speaking skill

\section{INTRODUCTION}

In Indonesia, English language is considered as the first international language which is taught in the education system. Thus, Indonesians assume that it is very important language which has been used in various aspects such as development of science, technology, education, business, culture and to establish the relationship with other countries in order to advance the nation. Although English is a foreign language for Indonesians, it is very interesting to be learned, studied, and used. Many experts and teachers have conducted some 
ways to make English easier to be learned and taught. One of those ways is by implementing English language as one of the compulsory subjects in the curriculum, especially for junior and senior high schools.

Further, since 2006, Indonesia has curriculum, School-Based Curriculum (SBC) or Kurikulum Tingkat Satuan Pendidikan (KTSP) as the educational system. Referring to National Education Standards Board or Badan Standar Nasional Pendidikan (BSNP)'s document of SBC, it focuses on achieving students' ability in a certain level of literacy such as cognitive ability and/or productive ability both in oral or written texts which is equally realized through four language skills; listening speaking, reading and writing. The level of literacy in Senior High School is to achieve informational level in which the students are able to access the knowledge about English using their language skills both oral and written skills because the students are prepared to continue their next education level or university level.

Since one objective of learning English as a foreign language is to be able to speak and use it in real communication (Alexandria, 2015), speaking skill seems to be the most important one in terms of judging students' effective ability to use the language. It is supported by Bailey and Savage (as cited in Alonso, 2013) who say that speaking in a second or foreign language has often been viewed as the most demanding of the other skills.

However, in some cases, some teachers found the difficulty to teach speaking because of some reasons which are the teaching's skill orientation and limited time allocation. Santy (2012) stated that English teaching activity in SMA is more only focused on reading and listening skills because these skills are widely tested during national exams. In fact, learning a language should not be oriented in those two skills but all the skills should be given equally. Other cases is found by Putra (2012) that, "the time allocation for English subject is about 90 minutes each to expose students in four language skills which is obviously minimum for exposure English ." Therefore, the students are difficult to speak English.

To cope this problem, the school should make a program (extracurricular) as a possible solution to make students learn English outside the regular classroom time in order to overcome their problem in English speaking skill. In SMA Ar-Rohmah Malang, the English teachers conduct a language program, named as Ar-Rohmah English Community (AEC) Program which must be followed by the students. AEC is considered as an extracurricular program which aims to give opportunities for the students to develop and express themselves based on their needs, talents, and interests (Permendiknas No. 22, 2006:12). The purpose of 
this extracurricular program is to support the students' English skills and their career in the future.

AEC Program in SMA Ar-Rohmah Malang is a set of activities that is conducted by the English teachers to upgrade and improve students' speaking skill as its goal. This program is implemented outside the regular classroom time, once a week on Saturday. This goal makes the teachers provide a lot of speaking activities such as discussion, speech, drilling vocabulary and storytelling performance. The students are asked to use English as their language communication during the implementation such as asking the question to their friends or teachers, informing their friends and giving responses and comments.

The aim of Ar-Rohmah English Community is to provide and increase the practice time using English. The names for this language program could be varied in other schools such as English Club, English Association, and so on. Nevertheless, the goal is all the same: to create English speaking improvement. Referring to the previous study conducted by Putra (2012), "English Club Program is a program that school has made to give students more exposure toward English speaking skill. This program is an extracurricular program so students can get more exposure outside the classroom."

By taking into account the entire situation mentioned above, the researcher considered to describe speaking skill activities used in Ar-Rohmah English Community (AEC) Program in SMA Ar-Rohmah Malang, to find out the problems related to teaching and learning English speaking skill in AEC, and to investigate the solution of the problems. The results of this study are expected to provide valuable contribution to betterment of the program.

\section{SPEAKING SKILL ACTIVITIES}

According to Bailey (2003: 64), "If you are teaching speaking, it is important to plan activities for small groups or pairs in language classrooms so the learners have a chance to practice these conversational skills without the teacher dominating the discussion." It means that if the teachers plan to make a speaking activity, they should consider about the students' chance of speaking. It is better to make students to participate more and be active in the activity of speaking. Harmer (2007: 348-352) classifies some of activities which can promote the students to speak:

1. Acting from a script

There are two activities covered: play script and acting out dialogues. Play script activity requires the students to act out scene from plays and/or their course book, 
sometime filming the results. While in acting out dialogues, students will often act out dialogues from which they have written themselves.

2. Communication games

The aim of this activity is to get students talking as quickly and fluently as possible. Information gap game is an activity which one student has to work in pairs and talk to the partner in order to solve the puzzle. Then, television and radio game refers to guessing game in which a student is given the object or thinks about an object and the team member have to find out what the object is by only asking yes/no questions.

3. Discussion

This activity gives students the opportunity to speak more freely and express themselves. It is helpful to structure a discussion activity by giving learners enough information about what they will be talking about and giving them enough time to think about what they want to say. The activity of discussion can be in the form of survey or questionnaire, instant comment, debates, unplanned discussion and reaching a consensus.

4. Prepared Talk

The teachers have told the students about the next activity and tell them to prepare a performance such as presentation, reporting news, storytelling and speech which have to be performed or presented in front of the class. Those activities involve individual work and take a lot of time, while the others listen to their friend's show

5. Simulation and Role Play

When the students do the simulation and role-play (such as a real life encounterbusiness meeting or interview), they need to know exactly what the situation is, and they need to be given enough information about the background but limited because we allow them to be as creative as possible. To add, drama can be considered as the speaking activity which can motivate students to speak. The activity refers to the set up of the play which includes the theater, the hall, the accessories, costumes, music etc (Aron, 2011). However, this activity need long time of preparation and be performed in high level of learning.

\section{THE PROBLEMS OF TEACHING AND LEARNING SPEAKING}

Problem is the difficulty faced by someone. According to Sadtono (as cited in Nirawati, 2009) there are two factors which can influence learning and teaching English which are linguistic and non-linguistic factors. It will be describe as the following: 


\section{Linguistic factor}

Linguistic factor are factors related to language itself such as grammar, vocabulary, pronunciation and language culture background. It can cause the problem for language users (teachers and learners) to speak and master English speaking skill.

a. Grammar

It is needed to arrange a correct sentence in conversation. The utility of grammar is also to learn the correct way to gain expertise in language, oral or written form

b. Vocabulary

It is defined as the appropriate diction which is used in communication. People cannot effectively communicate or express their ideas both in oral or written form if they do not have sufficient vocabulary.

c. Pronunciation

It is the way the students produce clearer language when they speak. It is concerned with the phonological process that refers to component of a grammar made up of the elements and principles that determine how sounds vary and pattern in a language

d. Language culture background

Teaching English in Indonesia, specially spoken language teaching can be very difficult. From the history, official status of English has been 'the first foreign language', and it is not and will never be a social language or the second official language (Musthafa, 2009). Indonesians have already been used to interacting and communicating or representing with the first language that is bound with cultural context. Thus, they need certain efforts to master English that mostly take place through teaching and learning process. Therefore, it is quite difficult to familiarize the students with English

2. Non-linguistic factor

Non-linguistic factors reflect to students, the teachers, methods, materials, time allocation and situation and condition.

a. The students

The source of problem can be from the students themselves. According to Ur (1996:121) there are some factors that make students difficult to speak, namely inhibition (students are worried and fear to make mistake, to be criticized or shy to be noticed), nothing to say (cannot express themselves), low participation (some learners 
are dominant) and mother tongue use (lack of motivation in result they are more natural to express themselves in their native language)

b. The teachers

The source of teaching speaking English problem is not only from students but also from teacher. As Indonesian English teachers, teaching quality can be influenced by the low educational qualification and lack of English language mastery as well as socio-economic factors (Suryanto, 2014). Moreover, Xu (2001) adds that teaching English can be very tiring because of large participation or classes. The teachers may feel physically weary because of using more energy to speak louder and move while psychologically, they feel intimidation to face a large 'crowd' of students

c. Method

This includes various procedures and techniques as part of the teacher's standard fare. By understanding students' characteristics, teacher will be able to choose suitable teaching methods or techniques for effectiveness

d. Material

It has important role in teaching and learning process. The material chosen should be selected and suitable with the goals of teaching

e. Facility

Facility is important to improve teaching and learning process to be success such as the provided good classroom, complete library, language laboratory, LCD etc

f. Time allocation

The lack of time allocation to teach English is another possible problem which can cause them difficult to develop their skill

g. Situation and condition

Situation and condition can affect the opportunity to practice English speaking. The result of monotonous teaching makes students do not have the opportunity to speak and practice because most of the activity in the classroom is teacher-center in which they have over-control of students and activity. Also, society influences toward English learning. The learners will be easy to study English, if the people in that society give positive responds or supports

\section{RESEARCH METHODOLOGY}


This study uses qualitative as the research design because it is presumed as the most proper design in order to get the answer of the research problems. Furthermore, it focuses on describing a specific context and developing the data more broadly, specifically in investigating the speaking skill activities used in Ar-Rohmah English Community (AEC) program in SMA Ar-Rohmah Malang. Moreover, it also aims to find out the problems related to teaching and learning speaking skill in AEC program and its solutions.

To get the source of data, the researcher has defined the population but it is still difficult for researcher to study large populations. Hence, she selects a smaller portion as a sample of the population. To select and choose the samples, the researcher uses simple random sampling as the sampling procedure. According to Creswell (2012:143), "in simple random sampling, the researcher selects the participants as the sample so that any individual has an equal probability of being selected from the population." As the result of taking the sample randomly, there are 3 groups consisting of 24 students. In addition, the researcher decides to use all of the two teachers as the major informants in conducting this speaking program. The reason to choose the samples is that they were involved in AEC Program where the teachers act as facilitators and the students as members.

Hence, in collecting the data, the researcher uses multiple methods which are observation, questionnaire, and interview. In observation, the researcher decides to use nonparticipant observation because the samples of this study are the students and the teachers who participate directly and establish the English Community program. Therefore, the researcher cannot participate to give and establish the program. it aims to get the data about speaking skill activities used in AEC Program and also the problems in teaching and learning speaking skill from students' and teachers' perspectives. In questionnaire, the researcher makes combination between closed-ended and open-ended questions. Questionnaires were given to the students in order to get information of their opinion about all the aspects related to speaking skill activities in Ar-Rohmah English Community Program such as (1) the speaking activities used in AEC; and (2) the students' problems related to teaching and learning English speaking skill. Then, interview is used to confirm the data from observation and questionnaire and also to investigate the solutions of the problems in teaching and learning speaking skill.

\section{FINDINGS AND DISCUSSIONS}

After gathering and analyzing the data through interview with the teachers on November 16, 2016, the researcher found that AEC Program was a new language program 
which focused on speaking skill improvement. The purpose of AEC was to provide the students with English environment and chance to speak in English freely through speaking activities (See interview transcript in Appendix 3, line 26, p. 64). The teachers created and planned to implement different activities every week. They tried to make interesting and fun activities in order to make students can practice their English speaking. Based on the data from observation result, the researcher found that the English teachers of AEC used and implemented seven speaking activities and these details are presented as follows:

1. Free Speaking

The teacher comes up with sudden and simple idea to do this activity. She just needs to organize the students by grouping them into pair discussion. Then, she chooses the topic which was simple to be thought by the students, 'What is the important thing in your life'. Free Speaking activity was described as discussion activity in which the students could talk freely about the topic given and dug the information as many as possible.

2. Card Game

The teachers called this activity as Card Game which was explained as one of speaking games. The theme picture of the card game was animals and things. The card game was played by pair group in which student $\mathbf{A}$ held the 5 pictures and student $\mathbf{B}$ chose one of it. Student B should not look the chosen picture. Instead, she tried to guess what the picture was by placing the backward-picture in her or forehead. She could guess by asking Yes/No questions to gather the clues. Then, after the clues were gathered, she could state her answer.

3. Watching Movie

This activity was sudden decision because the students complained and did not intend to have speaking activity. The students said they need refreshing and relax activity because they were bored and got stressed from midterm test. Hence, they have this activity as relaxing activity.

4. Interview

This activity has purpose to investigate some people (from AEC non-participants can be from students and teachers) to get the information about the identity, feeling about English, problem when speaking English, the solution of the problem, opinion and suggestion for AEC. The students have to make their own questions and find the targets. 
In addition, there were other speaking activities used by the teachers in the implementation of AEC Program such as storytelling, presentation of scientific work and dialogue. Though the researcher did not have chance to observe and obtained the data fully, but she get some of the data from students' questionnaires and interview result with the teachers. For storytelling activity, the researcher got the data from observation result in the first meeting. It showed that the teachers asked them to tell the story about their family and last vacation. They could present their story by facing the teachers one by one. The teachers made some rubrics to measure their speaking and gave them scores.

Based on the data from observation and questionnaires, the researcher found the problems related to teaching and learning English speaking skill in AEC Program. These problems were caused by linguistic and non-linguistic factors. It would be categorized into students' problems, teachers' problems and situation and condition problems. Each of them was described in the following parts:

\section{Students' Problems}

The problems are derived from linguistic and non-linguistic factors. The result of the problems was summarized that the linguistic factor which caused the problems to the students most was grammar. In contrary, vocabulary mastery caused fewer problems. Then, from non-linguistic factor, it showed that the students got the most problem from low participation and mother-tongue use aspects while nothing to say aspect was fewer caused the problems.

2. Teachers' Problems

The result showed that the two teachers faced some difficulties in teaching speaking skill in AEC Program. First problem, because of the students' amount and they were only two teachers in AEC, sometimes they felt very tired and confused. Second, it was so hard to tell the student to speak in English every Saturday morning. Third problem, they had lack of preparation time to prepare and meet the tutors because both of them had full agenda. Fourth, they could not remember the students' names. To add, from the result of observation, the researcher did not found any problems related to teachers' linguistic factor. Both of the teachers used well enough grammar and clear pronunciation as well as easy dictions.

3. Situation and Condition

The other problem related to situation and condition, before AEC Program was started, there was an outdoor activity called as Pandu Hidayatullah which influenced 
the students' passion toward AEC. The teacher said that this activity was very tiring activity. They felt exhausted when coming to AEC and their participation became low, and many of them were not active to speak.

In dealing with those problems above, based on the observation result and interview result, the English teachers clarified those problems with these solutions. For dealing with the students' problem from linguistic factors, the teachers tried to keep creating fun and interesting activities in the future. Hence, the students would not feel bored or sleepy. For the students' non-linguistic factors, the teachers could make evaluation from this research and try to always encourage the students to follow and enjoy the activity in AEC.

Furthermore, the teachers also solved their own problems which were stated in the interview result. For first problem's solution, they tried to get used to this new program for the next generation of AEC. The second solution was they created new regulations for the students or tutors who broke it, would get the punishment. They should ask the apology letter from head master and apology declaration before the public. She said that the hardship to ask the students using and speaking in English was decreased after the teachers created new regulations. Third, they would discuss the matter of preparation time with their curriculum teacher by asking extra time to do the preparation with the tutors. And the last solution of the problems, the teacher had asked the students to make a nametag and they should wear it every meeting in AEC. For situation and condition problem about outdoor activity influenced AEC Program, the teacher solved the problem using attractive activity.

Referring to the findings of this research, the teachers create this community to make an English environment in which the students can freely express themselves and also to provide the chance to speak in English. It is supported by Bailey (2003: 64), "If you are teaching speaking, it is important to plan activities for small groups or pairs in language classrooms so the learners have a chance to practice these conversational skills without the teacher dominating the discussion."

In line with Harmer's classification (2007: 348-353) about some of activities which can promote the students including acting from script (Dialogue), communication games (Card Game), Discussion (Free Speaking), Prepared Talk (Storytelling and Presentation of Scientific Work). In dialogue activity, the students were asked to write the short conversation and perform it with their partner. It is supported by Harmer (2007) that in acting out dialogues, students will often act out dialogues from which they have written themselves. And the teachers use card game as the communication game. In line with Harmer's explanation 
(2007) that television and radio game refers to guessing game in which a student is given the object or thinks about an object and the team member have to find out what the object is by only asking yes/no question. Though the teachers call it with card game, the description of activity is exactly same with Harmer.

In term of discussion activity, the teachers name the activity as free speaking in which the students speak freely to dig information as many as possible from the partner. It is in line with Harmer's explanation. And in term of prepared talk activity, the teachers use storytelling and presentation of scientific work. Furthermore, the teachers also use interview and watching movie activities. In line with this idea, Kayi (2006) says that interview is a good idea that the teacher provides a rubric to students so they know what types of questions they can ask or what path to follow, but students should prepare their own interview questions. Conducting interview with people gives the students chance to practice their speaking skill not only in class but also outside and helps them become socialized.

In addition, data from students' questionnaires shows that they like to have activities such as speaking games, refreshing activity and interview. They like speaking games because speaking games from puzzle solving and card game are fun to do and not boring. They can train their vocabulary bank. Likewise, refreshing activity which is watching movie is considered as one of ways to learn fun and entertaining English. Also, they like interview activity because they never experience an activity like interview in the class before in which they hunt the target and investigate them. It is media for them to try to be brave and confident using English when talking to other people. The students dislike free speaking, dialogue and presentation of scientific work. Those activities are considered as the boring and sleepy and take a long time to prepare such as writing the text and performing it

Besides, from the findings, it shows that there are problems found related to teaching and learning English speaking skill in the implementation of AEC Program which is viewed from linguistic and non-linguistic factors. Based on the research finding from questionnaires, the students have linguistic factor as the problems such as difficulty in vocabulary mastery, using suitable grammar, lacking teaching pronunciation, and not habituated with English. In line with Sadtono's explanation (as cited in Nirawati, 2009) that linguistic factor can influence learning and teaching English which causes the problem for language users.

Moreover, the students face the difficulties from non-linguistic factors which are from themselves such as inhibition, nothing to say, low participation, and mother-tongue use. The problems related to inhibition are the students feel worry and fear of making mistakes when using and speaking in English, and they are ashamed to be noticed when speaking in English. 
Besides, the students' problems related to nothing to say are they difficult to understand the instruction or topic which was given by the teacher and topic or instruction is too difficult or not interesting and fun. Other problems related to low participation are they are sacred to be blamed and criticized if they told their opinion in English and other students were more dominant in AEC and being underestimated. Last problems related to mother-tongue use are the students did not used to speak in English and they feel strange and ashamed when speaking in good English. Those findings support Ur's statement (1996) that students are inhibited (worried and fear making mistake, shy to be noticed), have nothing to say (cannot think anything and express themselves), have low participation (some learners are dominant) and mother-tongue use (feel easier and comfortable to share in mother language).

Based on interview result with the teachers, the problems from faced are the teachers sometimes are tired and confused to choose the activity. They feel hard to push and encourage the students to speak in English. In addition, they do not have enough time to prepare themselves and activity. Also, they cannot remember the students' names. These cases support Xu's explanation (2001) that teachers may feel exhausted both physically and psychologically and these conditions influence their teaching in large classes. Further, from the teachers' linguistic, there is no problems found.

The other problems are found related to non-linguistic factor which is situation and condition. There is outdoor activity before AEC Program is conducted which makes students tired and exhausted. In line with Sadtono's explanation (as cited in Nirawati, 2009) that situation and condition can affect the students' chance to practice English speaking. Though the activity is interesting and fun, the participation is low because other activity disrupts the students' passion toward English.

Overall, the teachers' solutions for the students' problems are to keep creating fun and interesting activities in the future and try to always encourage the students to follow and enjoy the activity in AEC. And also, they try to keep improving themselves from the energy and spirit, and asking some suggestion from other people.

\section{CONCLUSION}

From the findings discussed before, it can be concluded that in Ar-Rohmah English Communicity Program, the teachers use speaking activities to improve students' speaking skill which are Free Speaking, Card Game, Watching Movie, Interview, Storytelling, Presentation of Scientific Work and Dialogue. Besides, the problems found related to teaching 
and learning English speaking skill in AEC Program come from linguistic and non-linguistic factors. From students' linguistic factor, the problems are related to limited vocabulary, difficulty in using suitable grammar, lacking of pronunciation experience, and not habituated with English. Moreover, the non-linguistic factor, the problems come from the students themselves. They are reluctant to speak English because they are inhibited, have nothing to say, have low participation and feel ease and safe using mother language.

On the other hand, from the teachers' linguistic factor, there is no problem found. However, the problems related to non-linguistic factor come from the teachers themselves. Because there are only two teachers to handle the students in AEC Program, it is hard to deal with the large participants in AEC activities. The problems they face are fatigue, confused to choose suitable activity, not remembering well about the student's names, hard to motivate the students, and lack of preparation time. Also, other activity which is followed by the students influences their passion toward AEC Program. Although, the people in society (school and dormitory sections) support AEC but the busy schedule for both teachers and students influence AEC Program.

To deal with those problems, the teachers try to give some efforts which are to keep creating creative, fun and interesting activity in order to enhance the students' opportunity to speak English, improve their speaking skill in vocabulary, grammar, pronunciation and fluency aspects, and encourage them by always giving motivation to use English. The teachers also try to give their best to get used to this new program. Because sometimes they feel confused to choose suitable activity, they try to be more open to communicate with the tutors and other teachers to ask for the suggestions. Moreover, in order to solve the problem related to the students' low motivation to use English, the teachers create the regulations to be obeyed by both the tutors and the students who break the rules

\section{REFERENCES}

Alexandria, V.A. (2015). Standards for foreign language learning: Preparing for the $21^{\text {st }}$ century. Retrieved from

https://assessment.trinity.duke.edu/documents/StandardsforForeignLanguageLearning. pdf

Alonso, R. S. (2013). The importance of teaching listening and speaking skills (Master thesis, Universidad Compultense de Madrid). Retrieved from https://www.ucm.es/data/cont/docs/119-2015-03-17-12.RocioSeguraAlonso2013.pdf

Ary, D., Jacobs, L. C., Sorensen, C., \& Razafieh, A. (2010). Introduction to research in education ( $8^{\text {th }}$ ed.). Belmont, CA: Wadsworth. 
Badan Standar Nasional Pendidikan. (2006). Standar isi: Standar kompetensi dan kompetensi dasar SMA/MA. Retrieved from https://masdwijanto.files.wordpress.com/2011/03/buku-standar-isi-sma.pdf

Bailey, K. M. (2003). Exploring skills: Speaking. In D. Nunan, Practical English language teaching ( $1^{\text {st }}$ ed.). Singapore: McGraw-Hill

Creswell, J. W. (2012). Educational Research (4 ${ }^{\text {th }}$ ed.). Boston: Pearson

Dilip, Aron. (2011). Difference between drama and play. Retrieved from http://www.differencebetween.com/difference-between-drama-and-vs-play/

Exley, B. (2005). Learner characteristics of 'Asian' EFL students: Exceptions to the 'Norm'. In Young, Janelle, Eds. Proceedings pleasure passion provocation. Joint National Conference AATE \& ALEA 2005. Gold Coast, Australia.

Harmer, J. (2007). The practice of English language learning ( $4^{\text {th }}$ ed.). Harlow, England: Pearson Longman.

Hidayanti, D.S. (2007). The problems of learning speaking faced by the first semester students' of STTAD 'LEMJINATEK' Malang (Bachelor thesis, University of Muhammadiyah Malang). Retrieved from http://digilib.ta.um.ac.id/jiptummpp-gdl-s12007-hidayanti-100782\&q/

Kayi, H. (2006). Teaching speaking: Activities to promote speaking in a second language. The internet TESL Journal, XII. Retrieved from http://iteslj.org/Techniques/KayiTeachingSpeaking.html

Musthafa, B. (2009). English teaching in Indonesia: Status, issues and challenges. Retrieved from http://www.oocities.org/upis3/bm/english-teaching-in-indonesia.htm

Nirawati.(2009). The problems faced by the teachers in teaching speaking for ESP program at Communication Department of UMM (Bachelor thesis, University of Muhammadiyah Malang). Retrieved from http://digilib.ta.um.ac.id/jiptummpp-gdl-s1-2009-nirawati0410672\&q/

Nurlaeli, Sita. (2011). Improving students' speaking skill through Card Games (A classroom action research of 8 grade students of SMP Muhammadiyah Surakarta in 2010/2011 academic year). Retrieved from http://eprints.uns.ac.id/6516/1/209491711201104491.pdf

Peraturan Menteri Pendidikan Nasional. (2006). Nomor 22 tahun 2006: Standar isi untuk satuan pendidikan dasar dan menengah. Retrieved from http://sdm.data.kemdikbud.go.id/SNP/dokumen/Permendiknas\%20No\%2022\%20Tah un\%202006.pdf

Prayitno, M. (2006). The implementation of speaking program as extracurricular activity at SMAN 1 Tulungagung (Bachelor thesis, University of Muhammadiyah Malang). Retrieved from http://digilib.ta.um.ac.id/jiptummpp-gdl-s1-2006-mujiprayit-7502\&q/

Putra, Maulana. (2012). The implementation of English club program in teaching speaking skill (Bachelor thesis, Indonesia University of Education). Retrieved from http://aresearch.upi.edu/skripsiview.php?start=3853 
Santy, Betsu. (2012). Peningkatan keterampilan berbicara dengan pembelajaran bermain peran pada mata pelajaran Bahasa Inggris di SMAN I Gedongtataan Kabupaten Pesawaran (Bachelor thesis, University of Lampung). Retrieved from http://digilib.unila.ac.id/17480/

Sulastri, Euis. (2008). Peningkatan keterampilan berbicara formal dalam Bahasa Indonesia melalui Gelar Wicara: penelitian tindakan di SMAN 115 Jakarta. Jakarta: Program Pascasarjana Universitas Negeri Jakarta.

Suryanto. (2014). Issues in teaching English in a cultural context: A case of Indonesia. Retrieved from https://www.researchgate.net/publication/299978420

Ur, P. (1996). A course in language teaching ( $1^{\text {st }}$ ed). Cambridge United Kingdom: Cambridge University Press.

Virgiyanti, D. F. (2013). A study on English club as an extracurricular program at SMPN 1 Malang. Jurnal Online UM, 3. Retrieved from http://jurnalonline.um.ac.id/data/artikel/artike193F73AC0B8DDAAC022E49C2A5F457B16.pdf

$\mathrm{Xu}, \mathrm{Z}$. (2001). Problems and strategies of teaching English in large classes in the people's Republic of China. In A. Herrmann and M. M. Kulski (Eds), Expanding horizons in teaching and learning. Perth: Curtin University of Technology. Retrieved from http://clt.curtin.edu.au/tlf/tlf2001/xu.html

Yanda, F. (2014). Extracurricular program for student speaking improvement. Nobel Journal, 5. Retrieved from http://nobel.uinsby.ac.id/index.php/nobel/article/view/17/14 